\title{
The late increase in intracellular free radical oxygen species during apoptosis is associated with cytochrome $c$ release, caspase activation, and mitochondrial dysfunction
}

\author{
Q Chen ${ }^{1,4}$, Y-C Chai ${ }^{2,3}$, S Mazumder ${ }^{1}$, C Jiang ${ }^{4}$, RM Macklis ${ }^{2}$, \\ GM Chisolm ${ }^{3}$ and A Almasan ${ }^{\star 1,2}$ \\ ${ }^{1}$ Department of Cancer Biology, Cleveland Clinic Foundation, Cleveland, $\mathrm{OH}$ \\ 44195, USA \\ 2 Department of Radiation Oncology, Cleveland Clinic Foundation, Cleveland, \\ OH 44195, USA \\ ${ }^{3}$ Department of Cell Biology, Cleveland Clinic Foundation, Cleveland, $\mathrm{OH}$ \\ 44195, USA \\ 4 The National Key Laboratory of Biomembrane and Membrane Biotechnology, \\ Chinese Academy of Sciences, Beijing 100080, China \\ * Corresponding author: A Almasan, Departments of Cancer Biology and \\ Radiation Oncology, Lerner Research Institute, NB40, Cleveland Clinic \\ Foundation, Cleveland, OH 44195, USA. Tel.: 216444 9970; Fax: 216445 \\ 6269; E-mail: almasaa@ccf.org
}

Received 3.1.02; revised 12.8.02; accepted 20.8.02

Edited by $\mathrm{G}$ Salvesen

\begin{abstract}
Mitochondria play central roles in cellular metabolism and apoptosis and are a major source of reactive oxygen species (ROS). We investigated the role of ROS and mitochondria in radiation-induced apoptosis in multiple myeloma cells. Two distinct levels of ROS were generated following irradiation: a small increase observed early, and a pronounced late increase, associated with depletion of reduced glutathione (GSH) and collapse of mitochondrial membrane potential $\left(\Delta \psi_{\mathrm{m}}\right)$. Exogenous ROS and caspase-3 induced $\Delta \psi_{\mathrm{m}}$ drop and cytochrome $c$ release from mitochondria, which could be prevented by molecular (dominant-negative caspase-9) and pharmacologic (zVAD-fmk) caspase inhibitors and overexpression of Bcl-2. Exogenous ROS also induced mitochondrial permeability transition (PT) pore opening and cytochrome $c$ release in isolated mitochondria, which could be blocked by inhibition of PT with cyclosporin A. These results indicate that the late ROS production is associated with increased PT pore opening and decreased $\Delta \psi_{\mathrm{m}}$, and GSH, events associated with caspase activation and cytochrome $c$ release.

Cell Death and Differentiation (2003) 10, 323-334. doi:10.1038/ sj.cdd. 4401148
\end{abstract}

Keywords: apoptosis; reactive oxygen species; mitochondria; $\mathrm{Bcl}-2$; caspases; cytochrome $c$; glutathione; ionizing radiation

Abbreviations: cyt $c$, cytochrome $c$; $\mathrm{CM}-\mathrm{H}_{2}$ DCFDA; 2', 7'dichlorodihydrofluorescein diacetate; DEVD, acetyl-asp-glu-val- asp; DHE, dihydroethidium; fmk, fluoromethyl ketone; GSH, reduced glutathione; GSSG, oxidized glutathione; $\mathrm{H}_{2} \mathrm{O}_{2}$, hydrogen peroxide; IR, ionizing radiation; $\mathrm{mAb}$, monoclonal antibody; $\mathrm{PI}$, propidium iodide; PBS, phosphate-buffered saline; PT, mitochondrial permeability transition; ROS, reactive oxygen species; YVAD, acetyl-Tyr-Val-Ala-Asp; zVAD, Benzyloxycarbonyl-Val-Ala-Asp; $\Delta \psi_{\mathrm{m}}$, mitochondrial membrane potential

\section{Introduction}

Mitochondria play a central role in regulating apoptosis. ${ }^{1}$ During the initial phases of apoptosis, a wide variety of cellular signaling pathways are activated by cell death stimuli. These signals could consist of perturbations of redox and energy metabolism, ceramide generation, $\mathrm{Ca}^{2+}$ mobilization, or modulation of expression levels of Bcl-2 family members. Mitochondria sense the catastrophic cellular changes and irreversibly commit cells to apoptosis by releasing death factors into the cytosol, such as cytochrome $c$ (cyt $c$ ), ${ }^{1}$ Smac 2/DIABLO, ${ }^{2}$ AIF, ${ }^{3}$ EndoG, ${ }^{4}$ and Omi/HatrA2. ${ }^{5}$ The best characterized of these factors is cyt $c$, which plays a dual role in triggering apoptosis and maintaining the oxidative phosphorylation of mitochondria. Cyt $c$ is a soluble protein located in the mitochondrial intermembrane space, which functions as an electron carrier of the mitochondrial respiration chain between complexes III and IV. Once released into the cytosol, cyt $c$ binds to Apaf-1 to form a complex with caspase-9. ${ }^{6,7}$ This large complex, termed the apoptosome, which may contain as many as 20 additional proteins, initiates the activation of downstream caspases, which cleave cellular substrates at a specific tetra-peptide sequence on the carboxyl side of aspartate residues. ${ }^{8}$

$\mathrm{Bcl}-2$ is a proto-oncoprotein that functions at multiple levels to prevent morphological changes of apoptosis induced by diverse death stimuli. It has been suggested that $\mathrm{Bcl}-2$ could prevent apoptosis by regulating the cellular redox potential. Thus, Bcl-2 could act as an antioxidant by increasing the GSH pool or by redistributing GSH to various cellular compartments ${ }^{9}$ and prevent ROS production, GSH depletion, and cellular damage caused by lipid peroxidation. ${ }^{9-12}$ However, other reports indicate that $\mathrm{Bcl}-2$ could also function as a prooxidant. ${ }^{13}$ The mechanism of how $\mathrm{Bcl}-2$ regulates cellular redox potential and mitochondrial cyt $c$ release are not clear. $\mathrm{Bcl}-2$ and $\mathrm{Bcl}-\mathrm{X}_{\mathrm{L}}$ regulate the homeostasis of mitochondria by blocking cyt $c$ release from mitochondria and thereby preventing caspase activation. ${ }^{14-16}$ It was suggested that $\mathrm{Bcl}-2$ could be a general regulator of the mitochondrial homeostasis rather than simply a regulator of apoptosis. ${ }^{16,17}$ Alternatively, $\mathrm{Bcl}-2$ could regulate the mitochondrial permeability transition (PT) pore opening by opposing the effect of 
Bax, a component of the PT pore. ${ }^{18}$ The PT pore opening leading to collapse of mitochondrial inner transmembrane potential $\left(\Delta \psi_{\mathrm{m}}\right)$ was thought to be the irreversible step during the postmitochondrial execution phase of apoptosis. ${ }^{18,19}$ However, the relationships between the antioxidant properties of $\mathrm{Bcl}-2$ and its protective role in preventing cyt $c$ release and apoptosis have not been well established.

Mitochondria are the center for intracellular free radical oxygen production in the process of oxidative phosphorylation. During this process, $0.4-4 \%$ of the oxygen consumed in the cell is reduced to generate superoxide anions, $\mathrm{O}_{2}^{-}$which could be converted to hydrogen peroxide $\left(\mathrm{H}_{2} \mathrm{O}_{2}\right)$ by mitochondrial superoxide dismutase 2 (SOD2). $\mathrm{H}_{2} \mathrm{O}_{2}$ is then converted into $\mathrm{H}_{2} \mathrm{O}$ by mitochondrial $\mathrm{GSH}$ peroxidase at the expense of GSH or it participates in the Fenton reaction, giving rise to other ROS species, such as hydroxyl radicals $\left(\mathrm{OH}^{-}\right)$, the most damaging species of ROS. Reduced levels of cellular GSH can lead to increased steady-state concentrations of peroxides without an increase in their rate of ROS production, thus causing cellular oxidative stress. ${ }^{12}$ ROS have been implicated as second messengers in apoptosis, ${ }^{20}$ although other reports challenge this view. ${ }^{21}$ Nevertheless, mitochondrial ROS play a clear role in cellular cytotoxicity caused by TNF, Fas, p53, and viruses. ${ }^{22-24}$ Moreover, expression of SOD2, an antioxidant gene, was able to protect these cells from TNFinduced apoptosis. ${ }^{25}$ Mice lacking SOD2 show a profound increase in oxidative damage-related diseases and malfunction of mitochondria owing to oxidative damage. ${ }^{26}$ Although almost half of cancer patients are treated with ionizing radiation (IR), the mechanisms of IR-induced apoptosis with regard to its impact on mitochondria and ROS regulation are not known.

Recently, we reported that genotoxic stress and interferon-induced apoptosis in multiple myeloma cells are characterized by two distinct stages of cyt $c$ release and a positive feedback loop linking caspase activation to cyt $c$ release and mitochondrial dysfunction. ${ }^{27,28}$ This study further addresses the role played by ROS production in this model, by examining its effect on mitochondrial functions, release of apoptogenic factors such as cyt $c$, and caspase activation. We show that two distinct levels of ROS are generated following irradiation, with a pronounced, late ROS increase associated with reduced GSH levels, collapse of $\Delta \psi_{\mathrm{m}}$, and cyt $c$ depletion from mitochondria, events prevented by molecular and pharmacological caspase inhibitors and Bcl-2.

\section{Results}

\section{IR induces apoptosis blocked by ectopic bcl-2 expression}

We have previously characterized IR-induced apoptosis in IM9 cells. $^{27}$ This study has examined apoptosis in this multiple myeloma cell line and a derivative cell population stably expressing ectopic Bcl-2. Flow cytometric determination of the DNA content of control and irradiated propidium iodide (PI)-stained IM-9 and IM-9/Bcl-2 cells indicated that a sub-G1 cell population appeared at $24 \mathrm{~h}$ following IR (Figure 1a), an indication of the DNA loss following its fragmentation to a typical 123-bp DNA ladder. ${ }^{29}$ Overexpression of $\mathrm{Bcl}-2$ prevented the appearance of this sub-G1 population. The nuclease responsible for this DNA fragmentation in human cells has been identified as the DNA fragmentation factor (DFF) 40, which is activated following caspase-3-mediated cleavage of its inhibitor DFF $45 .^{4}$ Immunoblot analyses indicate, indeed, that DFF45 was proteolytically cleaved to its $35-\mathrm{kDa}$ derivative as early as $4 \mathrm{~h}$ after IR (Figure $1 \mathrm{~b}$ ). This cleavage was effectively inhibited by both the broad caspase inhibitor zVAD-fmk and Bcl-2 (Figure 1b). These findings are consistent with our previous report indicating that IR induces activation of caspase- 9 and caspase- 3 as early as $2 \mathrm{~h}$ after IR and that $\mathrm{Bcl}-2$ prevents activation of these caspases in IM-9 cells.

\section{ROS are produced in distinct stages during IR- induced apoptosis}

IR produces hydroxyl radicals $\left(\mathrm{OH}^{-}\right)$in aqueous solutions by direct radiolytic attack on $\mathrm{H}_{2} \mathrm{O}$. These hydroxyl radicals are capable of causing direct oxidative damage to cellular molecules, which result in DNA lesions, protein malfunctions, and lipid membrane peroxidation. ${ }^{10,30}$ Cells may respond to such damage by growth arrest, cell senescence, DNA repair or, if the damage is too severe to be repaired, undergo apoptosis. $^{31}$

We examined the production of the two most abundant ROS following irradiation, $\mathrm{O}_{2}^{-}$and $\mathrm{H}_{2} \mathrm{O}_{2}$, using oxidationsensitive fluorescent probes and flow cytometry. ${ }^{10,11,24}$ Examining the formation of $\mathrm{O}_{2}^{-}$anions by dihydroethidium (DHE) staining of IM-9 cells revealed a small early, as well as a significant (three-fold) later increase in superoxide anion levels (Figure 2a). We next determined the levels of $\mathrm{H}_{2} \mathrm{O}_{2}$, to which $\mathrm{O}_{2}^{-}$is converted by SOD, using CM-H2 DCFDA staining. ${ }^{10,11,24}$ Interestingly, we found that $\mathrm{H}_{2} \mathrm{O}_{2}$, similarly to $\mathrm{O}_{2}^{-}$, was also generated in two distinct phases following IR. First, there was a small but consistent increase, which appeared early and persisted for at least $8 \mathrm{~h}$ following irradiation (Figure 2b). In contrast, a more substantial twofold increase in $\mathrm{H}_{2} \mathrm{O}_{2}$ levels was observed at $16 \mathrm{~h}$ (Figure $2 \mathrm{~b}$ ), at a time we have previously reported to correspond to a latestage, massive, mitochondrial cyt $c$ release. ${ }^{27}$ Most cells displayed a readily detectable increase in $\mathrm{H}_{2} \mathrm{O}_{2}$ levels compared to untreated cells by $24 \mathrm{~h}$ following IR, with only a few cells remaining in which this increase in $\mathrm{H}_{2} \mathrm{O}_{2}$ did not take place. These ROS changes were determined only in the viable cell population (PI-negative and eliminating additional apoptotic cells by gating on a forward-scatter versus sidescatter dot plot), in order to exclude the possible contribution of ROS from necrotic cells (Figure 2c). As expected, exogenous $\mathrm{H}_{2} \mathrm{O}_{2}(0.1 \mathrm{mM})$, a well-known membrane permeable oxidant, ${ }^{10}$ induced a significant accumulation of cellular ROS in IM-9 cells following $5 \mathrm{~min}$ of treatment (data not shown). Bcl-2 did not prevent the small, early increase in the levels of $\mathrm{O}_{2}^{-}$and $\mathrm{H}_{2} \mathrm{O}_{2}$, but efficiently blocked the later stage of ROS production (Figure $2 \mathrm{a}-\mathrm{c}$ ). These analyses indicate the presence of constitutive levels of intracellular ROS in exponentially growing cells, which are further increased 

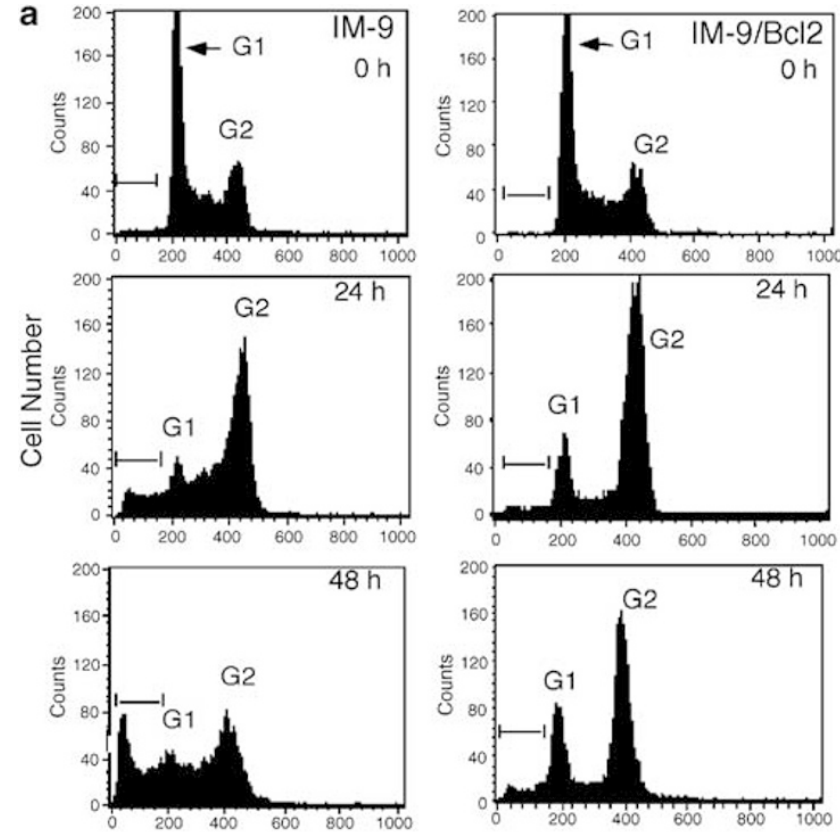

b

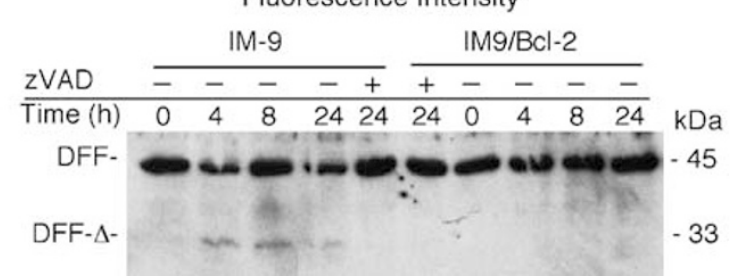

Figure 1 IR induces apoptosis, which is inhibited by $\mathrm{Bcl}-2$. (a) Flow cytometric assays for DNA content were performed in parental IM-9 and derivative cells expressing ectopic Bcl-2 (Clone 1-1), as described in the 'Materials and methods' section. The sub G1 DNA content is indicative of apoptotic cells. (b) IM-9 and IM9/Bcl-2 cells were irradiated in the presence or absence of the pancaspase inhibitor ZVAD-fmk and prepared for immunoblotting for DFF45 as described in the 'Materials and methods' section. The DFF45 proteolytic cleavage was examined following irradiation (10Gy) in the absence or presence of the pharmacologic caspase inhibitor zVAD-fmk and Bcl-2 overexpression. DFF$\Delta$ designates the truncated form of DFF45

immediately following IR. A more pronounced increase, contemporaneous with mitochondrial dysfunction, is observed at 16 and $24 \mathrm{~h}$ following treatment.

\section{Late increase of ROS and the reduction of $\Delta \psi_{\mathrm{m}}$ is inhibited by zVAD-fmk}

To determine the molecular determinants of ROS in apoptosis, we next examined whether activated caspases were required for ROS production. Caspase activation was measured following IR in the absence or presence of $z V A D$ fmk, or of the caspase-1 inhibitor, Ac-YVAD-cho. zVAD-fmk effectively prevented DEVD cleavage activity (Figure $3 a$ ) and apoptosis.

We have reported that the $\Delta \psi_{\mathrm{m}}$ reduction could be a consequence of cyt $c$ release and that it is inhibitable by zVAD-fmk and ectopic expression of Bcl-2 in IM-9 cells. ${ }^{27}$ To further examine the generality of these findings, we determined $\Delta \psi_{\mathrm{m}}$ in irradiated IM-9, IM-9/Bcl-2, and RPMI 8226 cells in the absence and presence of zVAD-fmk. We found that, similarly to IM-9, IR induced $\psi_{m}$ reduction in IR-sensitive RPMI-8226 multiple myeloma cells $16 \mathrm{~h}$ after IR, in a zVADfmk inhibitable manner (Figure 3b).

Since the late-stage ROS levels temporally followed caspase activation, we next examined the effect of caspase inhibitors on ROS production. Interestingly, zVAD-fmk prevented the late increase of $\mathrm{O}_{2}^{-}$and $\mathrm{H}_{2} \mathrm{O}_{2}$ generation resulting from mitochondrial cyt $c$ depletion, as assayed by $\mathrm{CM}-\mathrm{H}_{2}$ DCFDA or DHE staining and flow cytometry (Figure 3c, d). In contrast, YVAD-cho, which did not have any effect on caspase activity, could not prevent $\mathrm{H}_{2} \mathrm{O}_{2}$ elevation. zVAD-fmk inhibited the increase of ROS even when it was added at $8 \mathrm{~h}$ after IR, at the time when caspases were activated but when mitochondrial cyt $c$ levels remained unchanged (data not shown). The inhibition of ROS was not because of the effect of zVAD-fmk itself, since ZVAD-fmk had no effect on ROS levels assayed at an early time $(4 \mathrm{~h})$ in parental or Bcl-2 overexpressing IM-9 cells. These results are consistent with the observations that IR does not induce caspase activation in cells ectopically expressing $\mathrm{Bcl}-2$ at $24 \mathrm{~h}$. These data further reinforce the notion that the late, but not the early, increase of ROS is associated with caspase activity.

\section{Blocking caspase- 9 activation prevents cell death and increased ROS production}

We have previously shown that caspase- 9 and caspase- 3 are activated following the initial, low-level cyt $c$ release into the cytosol. ${ }^{27}$ Activation of the initiator caspase- 9 by cyt $c$ is considered to be a critical event for the activation of the caspase cascade, which may then further amplify cyt $c$ release, thus leading to ROS production and mitochondrial dysfunction. To test this hypothesis directly, we stably overexpressed a dominant-negative (DN) caspase-9 in IM-9 cells and examined its effects on cell death and ROS production. IR-induced apoptosis, as assayed by examining phosphatidyl-serine exposure on the plasma membrane, was significantly inhibited in caspase-9-DN-expressing cells as compared to that observed in parental IM-9 cells $24 \mathrm{~h}$ after IR (Figure 4a). Furthermore, the late-phase increase of $\mathrm{O}_{2}^{-}$ levels was completely inhibited, as assayed by DHE staining (Figure 4b). Caspase-9 protein levels were approximately sixfold higher in a representative clone, B-4, stably expressing caspase-9-DN, as compared to those in parental IM-9 cells (Figure 4c). The effects of caspase-9-DN in abrogating IRinduced ROS were comparable with that of $\mathrm{Bcl}-2$. These results strongly suggest a feedback control of $\mathrm{O}_{2}^{-}$production by a caspase-9-mediated caspase cascade in irradiated IM-9 cells.

\section{Radiation-induced depletion of reduced GSH is inhibited by Bcl-2 and zVAD-fmk}

Reduced glutathione (GSH) is a major antioxidant and protects cells from oxidative damage by scavenging peroxides in the cytosol and mitochondria. ${ }^{12}$ It has been reported 

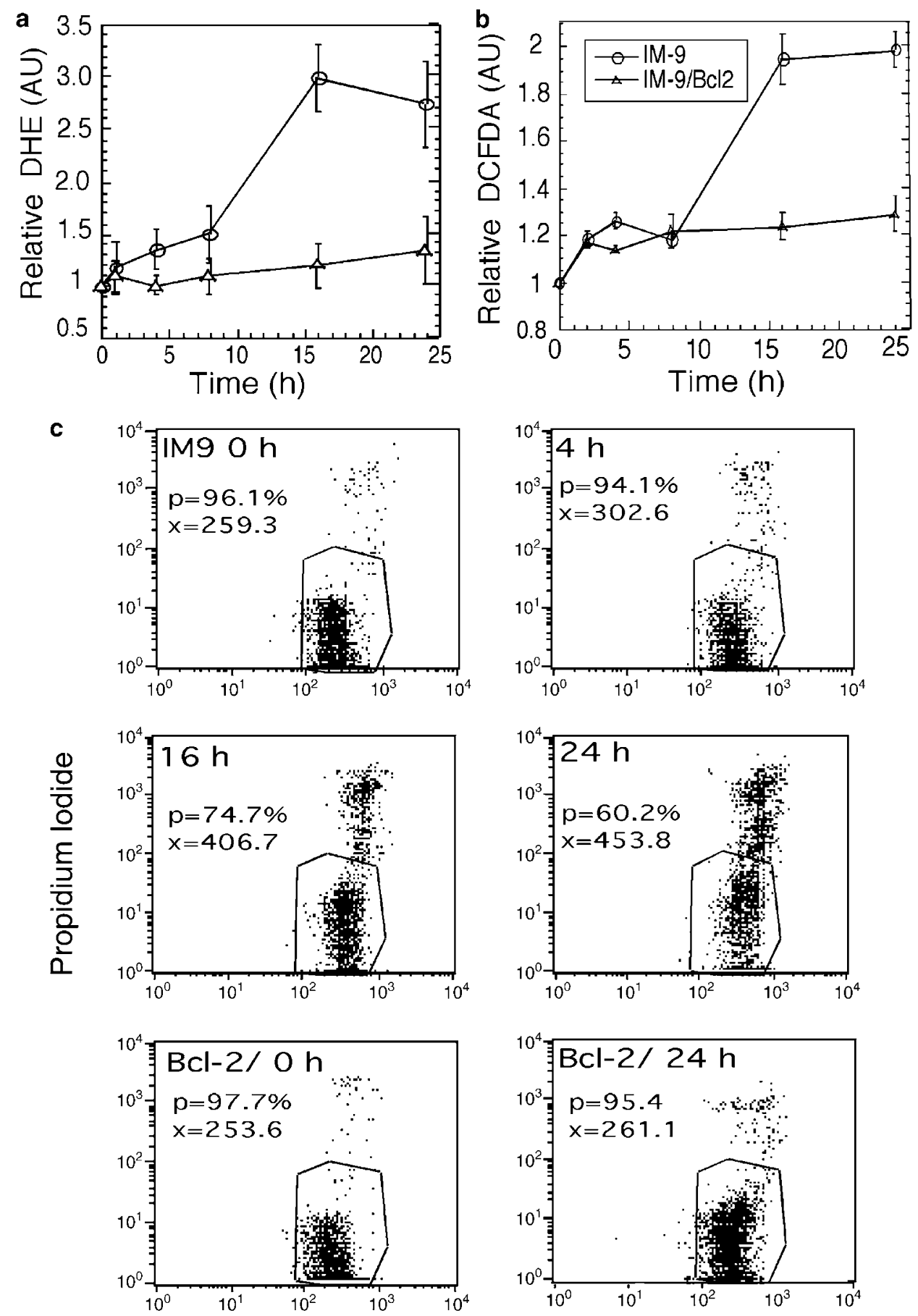

\section{Fluorescence (DCFDA) Intensity}

Figure 2 IR induces distinct phases of ROS production during apoptosis. Control or irradiated (10 Gy) IM-9 or IM-9/Bcl-2 cells were harvested at the indicated times and washed with serum-free medium, then incubated with $5 \mathrm{mM}$ DHE (a) or $1 \mathrm{mM}$ DCFDA (b, c) in PBS at $37^{\circ} \mathrm{C}$ for 10 min. The cellular fluorescence levels (FI-1, emission wavelength 620 or $530 \mathrm{~nm}$ ) were analyzed by flow cytometry, after the cell debris and PI-positive population were gated out. P: percentage of PI-negative cells; $x$. relative fluorescence. ROS levels, determined by DHE (a) or $\mathrm{H}_{2}$ DFCDA (b) staining, are presented as relative fluorescence of DCFDA or DHE. The dot plots shown (c) represent only the viable cell population and are presented gated as relative fluorescence of DCFDA. The mean value of FI-1 fluorescence was normalized against untreated cells. Data represent mean values from duplicate values from three separate experiments

that oxidative stress could lead to GSH consumption, which is also a major oxidant signal for apoptosis. ${ }^{12,32}$ We therefore examined the intracellular levels of reduced $(\mathrm{GSH})$ and oxidized glutathione (GSSG) in parental and Bcl-2 overexpressing IM-9 cells following IR. By using HPLC to determine the intracellular GSH and GSSG levels, we 

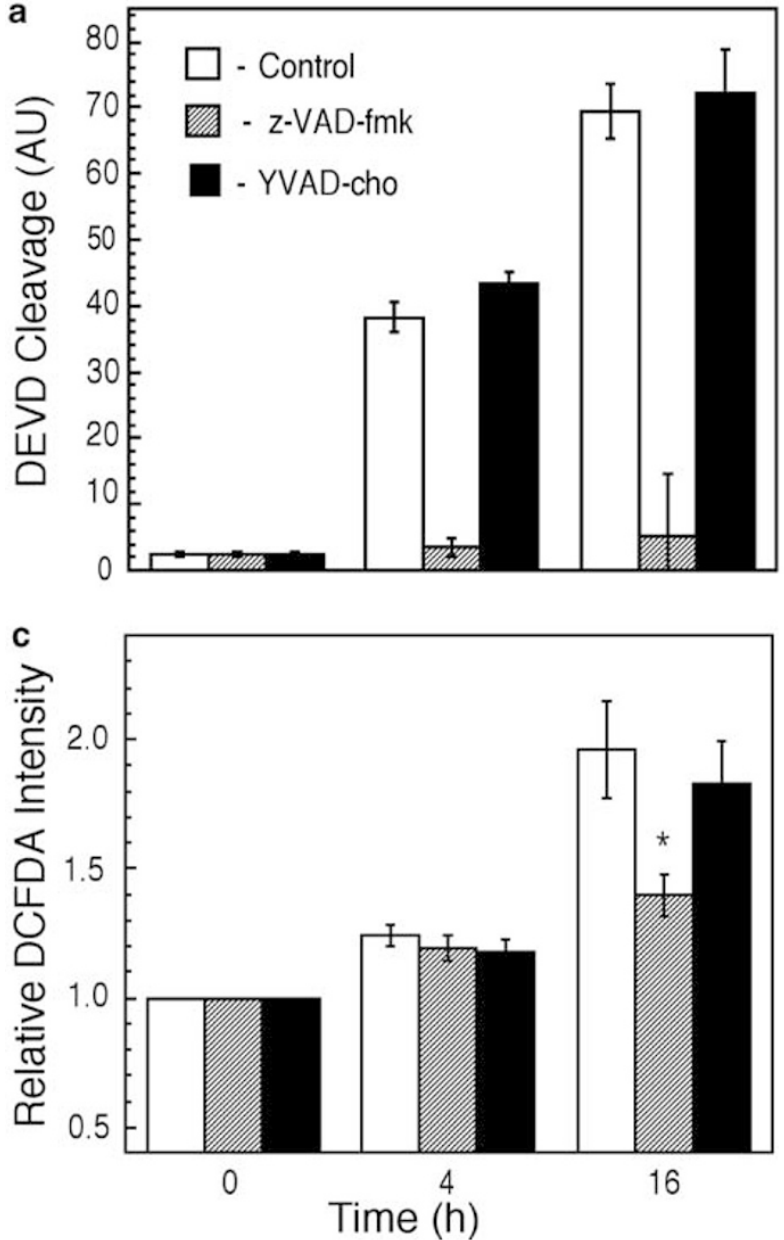

b

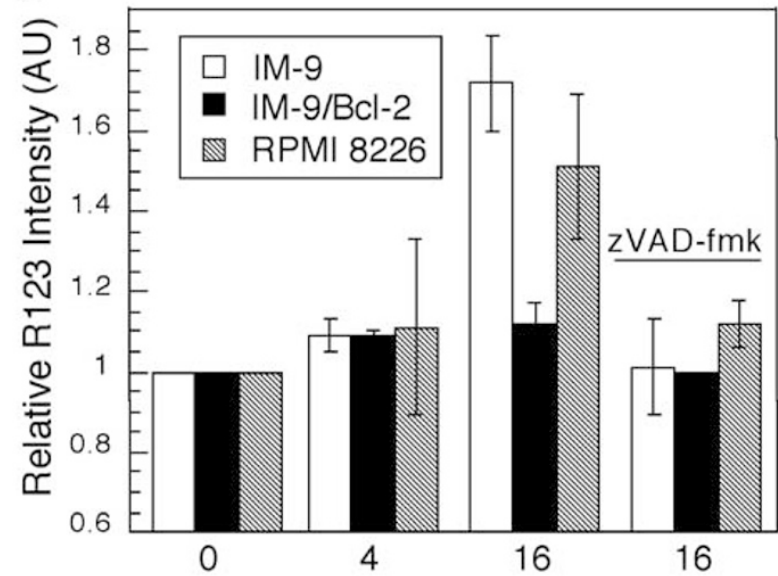

d

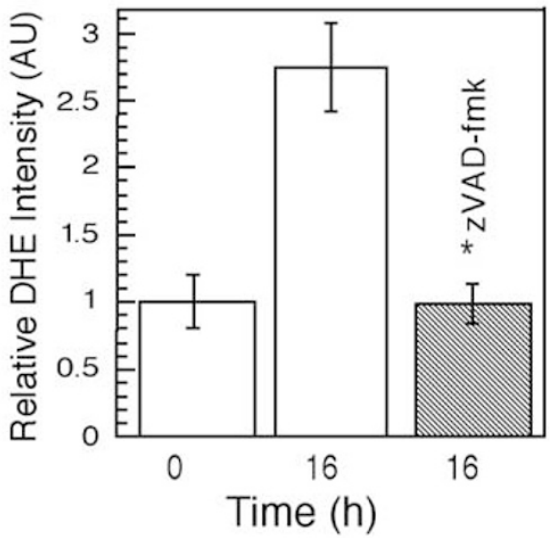

Figure 3 zVAD-fmk blocks DEVD cleavage activity and late ROS increase. (a) IM-9 cells were lysed at the indicated times following irradiation and assayed for caspase-3 activity toward the peptide substrate Ac-DEVD-p-nitroanilide, which was normalized to that of control cells. (b) The effect of IR on $\Delta \psi_{\mathrm{m}}$ was examined in IM-9 and RPMI-8226 cells, irradiated in the absence or presence of ZVAD-fmk. $\Delta \psi_{\mathrm{m}}$ was measured using R123 as described in the 'Materials and methods' section. Data were normalized against untreated cells and represent the mean values of three separate experiments. Cells were stained with $1 \mu \mathrm{M} \mathrm{CM}-\mathrm{H}_{2} \mathrm{DCFDA}$ (c) or $5 \mathrm{mM}$ DHE (d) and cellular fluorescence levels were analyzed by flow cytometry, similar to Figure 2. The data shown represent the mean values of two duplicate experiments. The values shown are for control, zVAD, and YVAD-treated cells as represented by empty, shaded, and filled symbols, respectively. ${ }^{*} P<0.05$, as determined by $t$-test

found that IR caused a 2.2-fold decrease in the levels of GSH as early as $2 \mathrm{~h}$, with almost all GSH being exhausted by $24 \mathrm{~h}$ (Table 1). In contrast, the levels of GSSG remained unchanged during this time, indicating that the depletion of GSH is specific. Therefore, the ratio of GSH to GSSG decreased following IR. In parallel experiments, we examined $\mathrm{GSH}$ levels in $\mathrm{Bcl}-2$ overexpressing cells. GSH levels in untreated IM-9/Bcl-2 cells were equivalent to those found in parental IM-9 cells. The GSH levels were only slightly decreased at $2 \mathrm{~h}$ after IR and were maintained at high levels at $24 \mathrm{~h}(80-85 \%$ of control). These data suggest that depletion of GSH following IR may be because of the increase of ROS, an event associated with caspase activation, and which can be prevented by $\mathrm{Bcl}-2$ overexpression.

Since zVAD-fmk may block the late ROS production through inhibition of caspase activity, we further examined the effect of caspases on GSH levels. Caspase inhibition by zVAD-fmk prevented the reduction of GSH levels at $24 \mathrm{~h}$ after $\mathrm{IR}$, indicating that caspases were important for the late GSH depletion. These results indicate that the GSH oxidation is an early event following irradiation, which intensifies by $24 \mathrm{~h}$, and that both $\mathrm{Bcl}-2$ and $\mathrm{zVAD}$-fmk prevent the late GSH depletion without affecting the initial decrease of GSH levels. Consistent with the above data, the GSH levels at $24 \mathrm{~h}$ following IR were unaffected in IM-9/caspase-9-DN cells (Table 1), further supporting the notion that caspase activation could result in ROS burst and an associated GSH exhaustion. The depletion of GSH was not because of the increase of peroxidase activity, which was unchanged following irradiation in both parental and ectopically expressing Bcl-2 cells (Chen and Almasan, unpublished). Buthionine-L-sulfoximine (BSO; $100 \mu \mathrm{M}$ ), a potent inhibitor of GSH synthesis, completely depleted GSH, but without affecting intracellular ROS levels and cell viability (data not shown). These data suggest that GSH depletion is not responsible for apoptosis induction by IR in IM-9 cells. Rather, GSH depletion may be a downstream event associated with the increase of ROS, most likely mediated by caspase activation. 
Table 1 Radiation-induced GSH depletion is inhibited by z-VAD-fmk, overexpression of Bcl-2 and DN caspase-9

\begin{tabular}{|c|c|c|c|c|c|c|}
\hline \multirow[b]{2}{*}{ Time (h) } & \multicolumn{2}{|c|}{ IM-9 } & \multicolumn{2}{|c|}{ IM-9/Bcl-2 } & \multicolumn{2}{|c|}{ IM-9/Casp9-DN } \\
\hline & GSH & GSSG & GSH & GSSG & GSH $^{*}$ & GSSG* \\
\hline $\begin{array}{l}0 \\
2 \\
6 \\
24 \\
24+z V A D\end{array}$ & $\begin{array}{l}8.35 \pm 2.55 \\
3.77 \pm 0.57 \\
4.30 \pm 1.49 \\
1.78 \pm 0.42 \\
6.10 \pm 1.92\end{array}$ & $\begin{array}{l}0.87 \pm 0.18 \\
0.78 \pm 0.13 \\
0.73 \pm 0.13 \\
0.73 \pm 0.18 \\
0.87 \pm 0.21\end{array}$ & $\begin{array}{c}8.72 \pm 1.55 \\
6.84 \pm 0.42 \\
7.40 \pm 1.45 \\
7.45 \pm 0.57 \\
\text { ND }\end{array}$ & $\begin{array}{c}0.96 \pm 0.13 \\
0.85 \pm 0.15 \\
0.90 \pm 0.18 \\
0.64 \pm 0.13 \\
\text { ND }\end{array}$ & $\begin{array}{l}9.8 \\
6.53 \\
6.32 \\
5.9 \\
\text { ND }\end{array}$ & $\begin{array}{l}0.81 \\
0.84 \\
0.72 \\
0.79 \\
\text { ND }\end{array}$ \\
\hline
\end{tabular}

Cells were irradiated (10 Gy) and incubated for the durations indicated. Cells were then harvested and GSH and GSSG (nM/mg protein) were assayed by HPLC. Data represent mean values from three separate experiments, unless indicated. ${ }^{*}$ Mean values of two separate experiments.

\section{ROS induce apoptosis, $\Delta \psi_{\mathrm{m}}$, and PT pore opening}

To determine whether ROS were responsible for cell death, we examined the effect of two well-characterized antioxidants, pyrrolidine-dithiocarbamate (PDTC; $50 \mathrm{mM}$ ) and $\mathrm{N}$ acetyl-L-cysteine (NAC; $10 \mathrm{mM}$ ), known to be capable of preventing the production of ROS and hence apoptosis. ${ }^{10,11}$ Both of these reducing agents significantly prevented IRinduced apoptosis (Figure 5a).

To mimic the effects of ROS production in mitochondria, we used the reaction of xanthine $(X)$ with xanthine oxidase $(X O)$ to generate $\mathrm{O}_{2}^{-} \cdot{ }^{33}$ The combination of $X(1 \mathrm{mM})$ with different concentrations of $\mathrm{XO}$ ( 0.01 or 0.1 units) induced apoptosis in a dose-dependent manner, as determined by annexin $\mathrm{V}$ staining (Figure $5 b$ ). In contrast, $\mathrm{X}$ or $\mathrm{XO}$ alone had no effect compared to treatment with vehicle alone. $\mathrm{H}_{2} \mathrm{O}_{2}$, a known oxidant, also induced annexin $\mathrm{V}$ staining when used at concentrations of 50 and $100 \mathrm{mM}$. ROS generated by the $\mathrm{X} / \mathrm{XO}$ system appeared to directly impact on mitochondrial PT, since 30 min of this treatment induced a reduction in $\Delta \psi_{\mathrm{m}}$, as determined by $\mathrm{R} 123$ staining and flow cytometry (Figure 5c).

To examine the effect of ROS on mitochondria directly, we carried out similar assays with isolated mitochondria. ROS generated by the $\mathrm{X} / \mathrm{XO}$ donor system could induce PT pore opening in mitochondria, as evidenced by the changes in light scatter properties determined by spectrofluorometry (Figure 6a). Moreover, we found that a similar treatment of mitochondria with exogenous ROS induced cyt $c$ release from mitochondria (Figure 6b). Cyt $c$ release was completely inhibited by cyclosporin A (CSA), indicating that PT was critical for cyt $c$ release. The effect of cyclosporin $A$ was specific as it also led, as expected, to the abrogation of the PT decrease caused by ROS (Figure 6a).

To further explore the mechanisms by which zVAD-fmk inhibits cyt $c$ release, and thereby the late increase of ROS production in IM-9 cells, we employed a cell-free system in which isolated mitochondria from untreated IM-9 cells were treated with recombinant caspase-3. Caspase-3 induced depletion of cyt $c$ from mitochondria in a concentrationdependent manner (Figure 6c). In contrast, the levels of another mitochondrial protein, MtCO1, were unchanged, indicating the specificity of cyt $c$ release. zVAD-fmk inhibited the caspase-3-induced cyt $c$ release. These data indicate that exogenous ROS could directly induce apoptosis and mitochondrial functional changes, such as the increased PT pore opening and cyt $c$ release in isolated IM-9 and mouse liver mitochondria. ROS has a profound effect on mitochondria by inducing the opening of the PT pore and loss of $\Delta \psi_{\mathrm{m}}$, events associated with cyt $c$ release and caspase activation.

\section{Discussion}

This study has found that the late increase of ROS production coincides with cyt $c$ release into the cytosol, both events likely to be mediated by caspase-induced feedback amplification. We have previously identified and characterized two distinct stages of cyt $c$ release into the cytosol during genotoxic stress-induced apoptosis. ${ }^{27} \mathrm{~A}$ two-step process for cyt $c$ release has been recently expanded and connected to the loosely and tightly bound pools of cyt $c$. The latter is attached to the inner mitochondrial membrane by its association with cardiolipin, an interaction that has to be disrupted to generate a soluble pool of this protein. ${ }^{34} \mathrm{~A}$ link between ROS production and mitochondrial cyt $c$ depletion during genotoxic stressinduced apoptosis is supported by data from this and our previous study. ${ }^{27}$ This late cellular ROS increase, associated with mitochondrial cyt $c$ depletion, is inhibited not only by $\mathrm{Bcl}-2$ but also by zVAD-fmk and caspase-9-DN, thus implicating caspases in a positive feedback control of mitochondrial functions, including ROS production. Recombinant caspase-3 induces cyt $c$ release (Figure 6 ), as well as ROS production and PT pore opening in isolated mitochondria. ${ }^{35}$ These data, taken together with our previous report, ${ }^{27}$ suggest that mitochondrial functions, such as reductions of $\Delta \psi_{\mathrm{m}}$, ATP, and GSH levels that occur during the late stages of apoptosis, are dependent on caspase activation and cyt $c$ release. These events are prevented by molecular and pharmacological caspase inhibition and by $\mathrm{Bcl}-2$ overexpression.

The regulation of ROS and its role in apoptosis have not been resolved. It has been generally believed that cyt $c$ release from mitochondria could lead to the production of cellular ROS. ${ }^{36,37}$ Our results, suggesting caspase participation in the late increase of ROS production during apoptosis, reconcile a large body of recent contradictory reports on ROS regulation during apoptosis in different systems. ${ }^{38,39}$ Kroemer and colleagues ${ }^{40}$ first connected a protease activation pathway to the mitochondrial phase of apoptosis regulation. Two phases of ROS were also reported in a model of apoptosis induced by glutamate in HT22 cells, with zVAD-fmk also inhibiting ROS production. ${ }^{38}$ In contrast, a recent report 

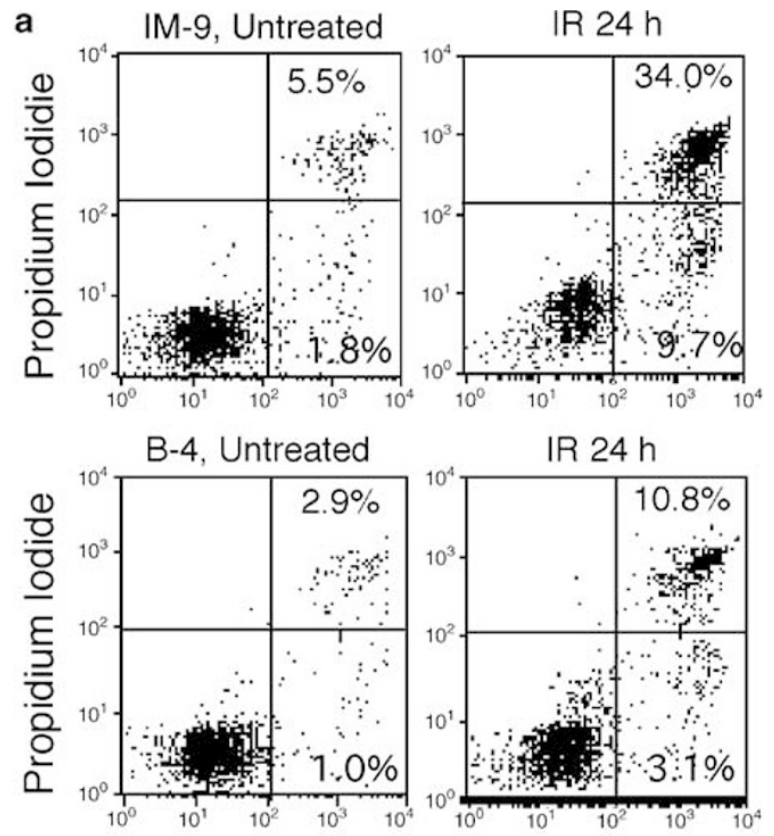

b

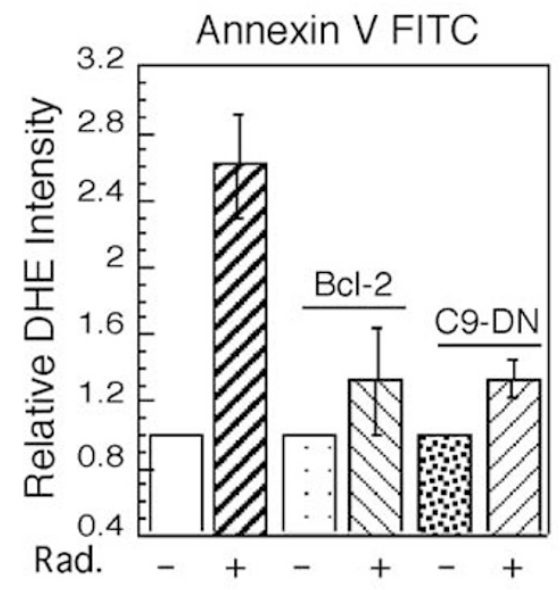

c

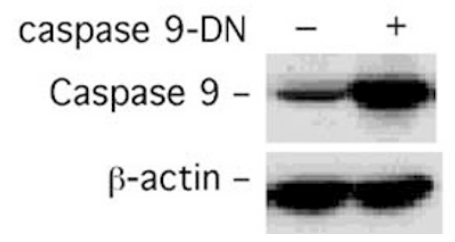

Figure 4 Caspase-9-DN inhibits IR-induced apoptosis and late increase in ROS. (a) IM-9 cells were transfected and selected for expression of caspase-9DN. Clone B-4, which abundantly expressed caspase- 9 and parental IM- 9 cells were then used to examine phosphatidylserine exposure, an early marker of apoptosis, by annexin V staining and flow cytometry. (b) Parental IM-9 or derivative cells ectopically expressing Bcl-2 or caspase-9-DN were subjected to DHE staining and flow cytometry at $24 \mathrm{~h}$ following irradiation, as described above. The data shown are mean values of three experiments with duplicate samples and are representative of three separate experiments. (c) Level of expression of caspase- 9 as determined by immunoblotting with anti-caspase- 9 , and as a control, anti- $\beta$-actin primary antibodies. DN, dominant-negative

suggests that cyt $c$ release from mitochondria is an 'all or nothing' event. ${ }^{41}$ Our previous results implicating a feedback amplification of cyt $c$ release by caspases ${ }^{27}$ are not contradictory but rather complementary to this observation. It is possible that only a small proportion of mitochondria within any individual cell open the PT pore following irradiation, resulting in release of cyt $c$ from the affected mitochondria. This small amount of cyt $c$ may be sufficient to activate caspases, which in turn may cause a feedback amplification of cyt $c$ release by inducing ROS production and PT pore opening in neighboring mitochondria. If this is the case, caspases could represent an amplifying signal responsible for the overall cellular mitochondrial dysfunction. It is not known whether other molecules, such as BH3-domain only or multidomain $\mathrm{Bcl}-2$ family proteins, ${ }^{42}$ are also involved in this amplification process. Interestingly, Bid does not seem to be activated in irradiated IM-9 cells. ${ }^{27}$ Determining ROS production in individual mitochondria and establishing whether ROS per se is responsible for the PT pore opening and cyt $c$ release in vivo, remain among the technical challenges ahead.

The relationship between ROS and mitochondrial functional readouts, such as cyt $c$ release and $\Delta \psi_{\mathrm{m}}$ reduction, and other related apoptotic events are not clear. Our examination of mitochondrial apoptotic determinants following IR points to their activation downstream of the early stage, limited cyt $c$ release. Indeed, treatment of isolated mitochondria with caspase-3 directly induces PT pore opening and massive cyt $c$ release, events inhibited by $B c l-x L$, cyclosporin $A$, and zVAD-fmk. ${ }^{35}$ It is possible that caspase-3 could directly target the PT pore to induce the massive cyt $c$ release and subsequent apoptosis. Recently, it has been shown that caspase-2 may also cause release of cyt $c$ from mitochondria. ${ }^{43-45}$ These data are consistent with reports indicating that cyt $c$ could be released either before or after PT pore opening, depending on the cell system and the death stimuli. ${ }^{42} \mathrm{~A}$ number of apoptotic stimuli, including ROS, impact on PT pore opening to induce cyt $c$ release and apoptosis. Our data indicate that ROS generated by the X/XO reaction could directly affect $\Delta \psi_{\mathrm{m}}$ through induction of PT, as suggested. ${ }^{33} \mathrm{PT}$ pore opening could then lead to more cyt $c$ release and a further increase in ROS levels. ${ }^{27,46} \mathrm{It}$ is possible that there is a self-amplifying loop that depends on ROS, cyt $c$ release, caspase activation, and PT.

Understanding the complex functional relationships between the biochemical and metabolic hallmarks for apoptosis, such as cyt $c$ release, caspase activation, ROS production, PT, and GSH depletion, and their regulation by $\mathrm{Bcl}-2$ are important for advancing our knowledge of apoptosis. The redox potential and cellular ROS are known to be influenced by a number of endogenous and exogenous processes and under the control of several radical producing and scavenging enzymes. ${ }^{47} \mathrm{GSH}$ is the major intracellular free radical scavenger and reacts rapidly and nonenzymatically with different types of free radicals during normal metabolic processes and during oxidative stress. One of the consequences of the late ROS increase could be the depletion of $\mathrm{GSH}$, both events being associated with secondary necrosis, a phenomenon known to be associated with the late stages of apoptosis. Sequential cellular changes are characterized by GSH depletion followed by increased ROS production, with these cells manifesting a near-to-simultaneous $\Delta \psi_{\mathrm{m}}$ dissipation and GSH depletion early during the apoptotic process. ${ }^{32}$, ${ }^{46}$ In agreement with these reports, we observed that the GSH levels decreased following IR, becoming depleted $24 \mathrm{~h}$ later in 

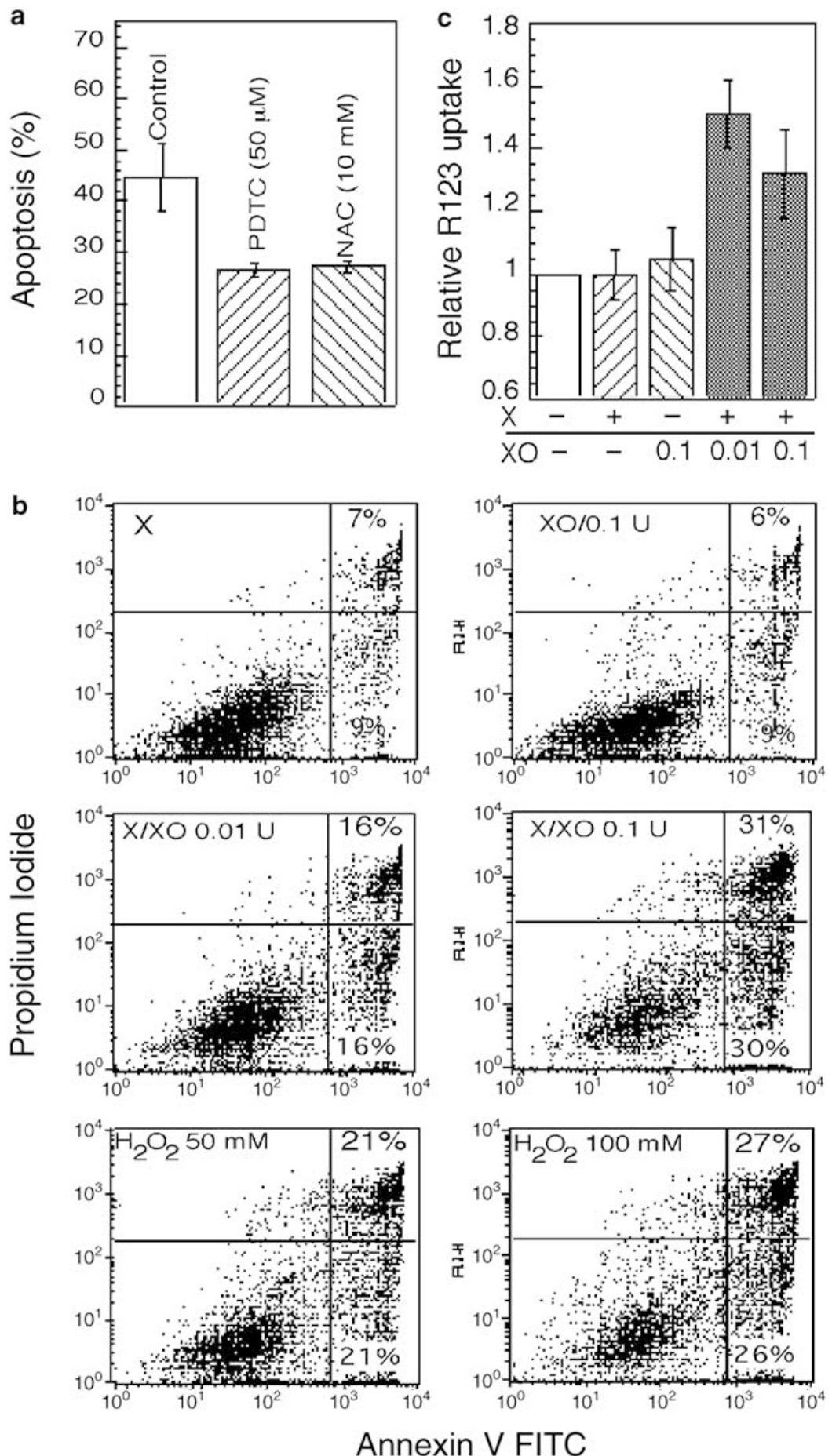

Figure 5 Effect of anti- and pro-oxidants on apoptosis and $\Delta \psi_{\mathrm{m}}$. (a) Morphological changes characteristic of apoptosis were determined by DAPI staining in cells pretreated with the antioxidants PDTC $(50 \mu \mathrm{M})$ and NAC $(10 \mathrm{mM})$ for $1 \mathrm{~h}$ before irradiaton $(10 \mathrm{~Gy})$. Apoptosis was then examined at $28 \mathrm{~h}$ after IR. The data represent mean values from three separate experiments. (b, $\mathbf{c})$ The effect of xanthine $(\mathrm{X})$ and xanthine oxidase $(\mathrm{XO})$ on apoptosis and $\Delta \psi_{\mathrm{m}}$ was examined in cells treated with $\mathrm{X}$ and $\mathrm{XO}$, alone or in combination, or $\mathrm{H}_{2} \mathrm{O}_{2}$ for 30 min at $30^{\circ} \mathrm{C}$ and then subjected to $\mathrm{R} 123$ staining (c) or incubated in complete medium for $24 \mathrm{~h}$ before annexin $\mathrm{V}$ staining and flow cytometry (b)

IR-sensitive cells, at the time at which PT pore opening and ROS were induced. GSH depletion was inhibited by ZVADfmk, caspase-9-DN, and Bcl-2. Moreover, BSO could completely deplete GSH without any significant impact on intracellular ROS and cell viability. Taken together, these data suggest that the late GSH depletion is the consequence, at least in part, of caspase-mediated mitochondrial dysfunction and ROS production, although the mechanisms of GSH depletion and the cause of the early GSH consumption remain to be determined. 
a

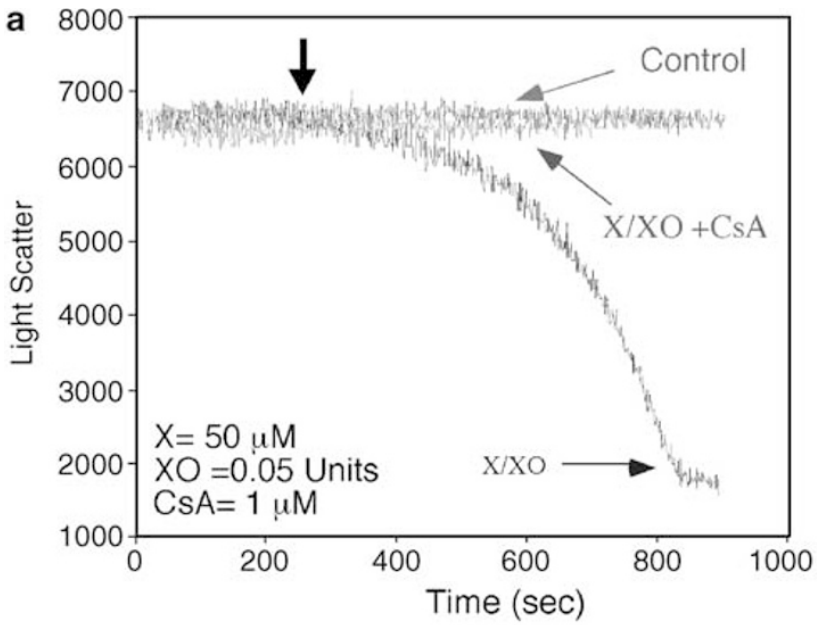

\begin{tabular}{|c|c|c|c|c|c|}
\hline $\mathrm{X}(50 \mu \mathrm{M})$ & - & + & - & + & + \\
\hline$\underline{\mathrm{XO}}(20 \mathrm{U} / \mathrm{ml})$ & - & - & + & + & + \\
\hline $\operatorname{CsA}(1 \mu \mathrm{M})$ & - & - & - & - & + \\
\hline Supernatant & & & $x=$ & inses: & \\
\hline Loading Cont. & nestes & semes & wases & $=0$ & dewes \\
\hline
\end{tabular}

C

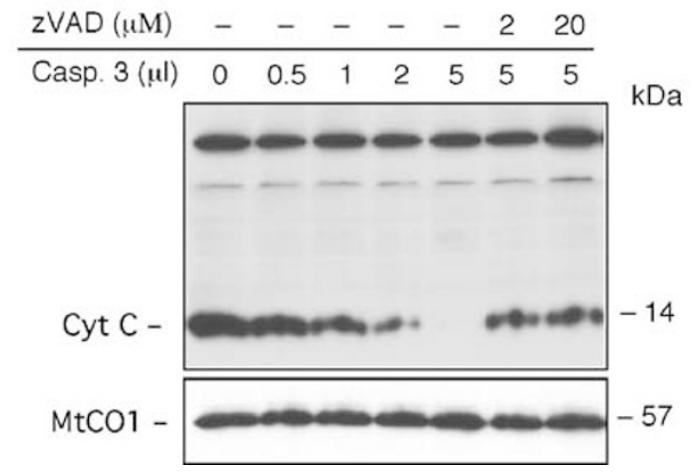

Figure 6 Effect of ROS and caspase-3 on isolated mitochondria. (a) The effect of ROS generation from the reaction of $X$ with $X O$ on PT pore opening was examined in isolated mitochondria from mouse liver, as described in the 'Materials and Methods' section. XO was added at the indicated times with X being added as designated by the arrow. Control and CsA represent mitochondria alone or those treated with cyclosporin $\mathrm{A}(1 \mu \mathrm{M})$ in addition to $\mathrm{X}$ and $X O$. (b) The release of cyt $c$ from $X / X O$-treated mouse liver mitochondria was determined by immunoblotting with an anti-cyt $c$ antibody. Loading control represents a nonspecific antibody-reactive band. (c) P10 mitochondrial fractions from IM-9 cells were incubated with different concentrations of recombinant caspase-3 in the absence, or presence, of the pancaspase inhibitor ZVAD-fmk at $30^{\circ} \mathrm{C}$ for $2.5 \mathrm{~h}$. The reaction mixtures were then pelleted and examined for cyt $\mathrm{C}$ levels by immunoblotting with anti-cyt $c$ mAb

At least two major functions are attributed to the protective role of $\mathrm{Bcl}-2$ in apoptosis, its regulation of the cellular redox potential and cyt $c$ release from mitochondria. We find that $\mathrm{Bcl}-2$ prevents the late GSH depletion and increased ROS production. Bcl-2 itself is known to be able to increase the intracellular levels of GSH or mobilization in some systems, ${ }^{12}$ although generalization of these findings may be difficult.
However, the mechanism by which Bcl-2 acts to maintain cellular GSH levels is not clear. Bcl-2 overexpression appears not to impact on the initial GSH loss in our system, but rather prevents further loss of GSH at $24 \mathrm{~h}$. In cells expressing high levels of ectopic Bcl-2, in which cyt $c$ release is blocked, there was no significant late-phase change in cellular ROS and GSH levels. Our data strongly indicate that $\mathrm{Bcl}-2$ prevents GSH depletion by blocking cyt $c$ depletion mediated by caspases and the subsequent ROS increase, thus reconciling its dual role in regulating cyt $c$ release and redox potential. This further reinforces the notion that the functions of $\mathrm{Bcl}-2$ in regulating the redox potential, ROS production, and cyt $c$ release from mitochondria are inter-related, and the suppression of cyt $c$ release could be the primary function of $\mathrm{Bcl}-2$. Thus, our results are consistent with a large body of evidence indicating that $\mathrm{Bcl}-2$ prevents caspase activation, cyt $c$ release, GSH depletion, and the associated mitochondrial dysfunction. We extend these observations further to a critical role for $\mathrm{Bcl}-2$ in preventing the late-stage increase in cellular ROS and decrease in GSH levels, likely to be achieved by blocking the caspase-mediated amplification of cyt $c$ release.

In summary, we provide evidence for two distinct phases of ROS generated following irradiation. A pronounced late ROS increase is associated with increased PT pore opening and reduced GSH, and $\Delta \psi_{\mathrm{m}}$, all events that can be prevented by molecular and pharmacologic caspase inhibitors and $\mathrm{Bcl}-2$. Exogenous ROS induce PT pore opening and cyt $c$ release directly in isolated mitochondria, indicating that the late ROS production is associated with critical mitochondrial functions, likely to be tightly linked to caspase activation and cyt $c$ release.

\section{Materials and Methods}

\section{Cell culture and treatments}

IM-9 and RPMI-8226 multiple myeloma cells were obtained from the American Type Culture Collection and cultured at $37^{\circ} \mathrm{C}$ in a $5 \% \mathrm{CO}_{2}$ incubator in RPMI 1640 medium, supplemented with 10\% heat-inactivated fetal bovine serum, $100 \mathrm{units} / \mathrm{ml}$ penicillin, $100 \mathrm{mg} / \mathrm{ml}$ streptomycin, and $2 \mathrm{mM}$ L-glutamine (InVitrogen, Inc.). Exponentially growing cells were subject to $\gamma$-irradiation ${ }^{31}$ or incubated with the indicated amount of xanthine oxidase $(X O)$ in the presence of $1 \mathrm{mM}$ xanthine $(X)$ in phosphatebuffered saline (PBS) and assayed for ROS. The generation of ROS by the $\mathrm{X} / \mathrm{XO}$ system, as revealed by the luminol assay, showed a burst of ROS immediately after mixing $X$ with $X O$.

DN caspase-9 and pSFFV-neo FLAG.BCl-2 (gifts from A Alnemri ${ }^{6}$ and $G$ Nunez ${ }^{48}$ ) were used for stable transfection of IM-9 cells. Individual clones stably expressing different levels of ectopic $\mathrm{Bcl}-2$ and caspase-9DN were isolated by limited dilution in neomycin $(0.7 \mathrm{mg} / \mathrm{ml})$-containing medium following transfection $\left(1 \times 10^{6} \mathrm{cell} / \mathrm{s} / \mathrm{ml}\right)$ using $2 \mu \mathrm{g}$ DNA and $4 \mu \mathrm{g}$ DMRIE-C reagent in OPTI-MEM I (Invitrogen, Inc.).

\section{Caspase-3-like protease assay}

Cells $\left(3 \times 10^{5}\right)$ were washed with PBS, lysed on ice in 25 mM HEPES $(\mathrm{pH}$ 7.4), $0.5 \%$ NP- $40,2 \mathrm{mM}$ EDTA, and $1 \mathrm{mM}$ DTT in the presence of a protease inhibitor cocktail. The lysates were centrifuged at $13,000 \mathrm{rpm}$ for $12 \mathrm{~min}$ at $4^{\circ} \mathrm{C}$ and assayed for protease activity using $40 \mu \mathrm{g}$ of protein and $100 \mathrm{nM}$ of acetyl-Asp-Glu-Val-Asp-p-nitroanilide (Ac-DEVD-p-nitroanilide) 
substrate..$^{27,31}$ Samples were incubated at $30^{\circ} \mathrm{C}$ for $60 \mathrm{~min}$, after which the enzyme-catalyzed release of $p$-nitroanilide was monitored by measuring optical density at a wavelength of $405 \mathrm{~nm}$ using a microplate reader. In some experiments, the cell lysates were first incubated with the caspase inhibitors benzyloxycarbonyl-Val-Ala-Asp-fluoromethylketone (zVAD-fmk) or acetyl-Tyr-Val-Ala-Asp-cho (YVAD) on ice for $30 \mathrm{~min}$. Caspase peptide inhibitors or substrates were from CalBiochem; all other chemicals were from Sigma Chemicals, unless otherwise specified.

\section{Immunoblot analysis}

Cells were washed in PBS and lysed in buffer A containing $150 \mathrm{mM} \mathrm{NaCl}$, $25 \mathrm{mM}$ HEPES pH 7.4, 1\% (v/v) NP-40, 0.25\% (w/v) sodium deoxycholate, $1 \mathrm{mM}$ EGTA, EDTA, and PMSF, $10 \mathrm{mg} / \mathrm{ml}$ aprotinin, leupeptin, and pepstatin. Cellular proteins from total cell lysates (10 $\mu \mathrm{g} /$ sample) were separated by SDS-PAGE and transferred onto a nitrocellulose membrane (Schleicher and Schull). The membranes were probed using immunoblot analyses with mAbs specific to the human caspase-9, DFF45 (Santa Cruz), cyt $c$ (Pharmingen), or Cyt Oxidase I (MTCO1) (Molecular Probes) followed by incubation with the secondary antibody conjugated to horseradish peroxidase for $1 \mathrm{~h}$ at room temperature. Equal protein loading was confirmed by staining the filters with Ponceau $S$ and/or reprobing with anti- $\beta$ actin $\mathrm{mAb}$ (Sigma). Immunoreactive bands were detected using enhanced chemiluminescence (Amersham) and visualized by autoradiography.

\section{Cell fractionation and in vitro cell-free assay for caspase-induced cyt $c$ release}

Cells $\left(5 \times 10^{6}\right)$ were washed twice with ice-cold PBS and kept on ice in buffer containing $20 \mathrm{mM}$ HEPES-KOH (pH 7.2), $100 \mathrm{mM} \mathrm{KCl}, 1.5 \mathrm{mM}$ $\mathrm{MgCl}_{2}, 1 \mathrm{mM}$ EDTA, $1 \mathrm{mM}$ EGTA, $250 \mathrm{mM}$ sucrose, and protease inhibitors (1 mM PMSF and DTT, $10 \mathrm{mg} / \mathrm{ml}$ aprotinin, leupeptin, and pepstatin). Cells were irradiated at different time points and harvested at the same time for cell fractionation. ${ }^{27}$ The cell suspension was homogenized with a Dounce homogenizer (5-8 strokes), the homogenates were centrifuged at $750 \times g$ for $5 \mathrm{~min}$, and the supernatants were subjected to further centrifugation at $10000 \times g$. The pellets containing mitochondria were designated as $\mathrm{P} 10$. The supernatants were then subjected to further ultracentrifugation at $100000 \times g$ for $45 \mathrm{~min}$. The resulting pellets and supernatants, representing the endoplasmic reticulum and cytosolic fractions, were designated as P-100 and S-100, respectively. Cell fractions were examined by Western blotting for the presence of (MTCOI) or porin (mitochondria), calnexin (ER), and PCNA (nuclei), and no crosscontamination was detected.

The in vitro cell-free assay for caspase-induced cyt $c$ release consisted of the $\mathrm{P}-10$ fraction ( $30 \mu \mathrm{l}$, containing $2 \mu \mathrm{g} / \mu \mathrm{l}$ protein) mixed with recombinant caspase-3, as indicated, in the presence of $1 \mathrm{mM}$ DTT and incubated at $30^{\circ} \mathrm{C}$. In certain experiments, the samples containing caspase inhibitors $(100 \mathrm{nM})$ were preincubated on ice for $30 \mathrm{~min}$. The samples were then centrifuged and the pellets were assayed for cyt $c$, or as a control MTCO1, by immunoblotting.

\section{Flow cytometric assays}

To detect phosphatidylserine exposure on cell membranes, IM-9 cells were stained with FITC-Annexin V, simultaneously with dye exclusion of $\mathrm{PI}^{27}$ This assay discriminates among intact cells (FITC-/PI-), early apoptotic cells (FITC+/PI-), and late apoptotic or necrotic cells (FITC+/ $\mathrm{PI}+$ ). For DNA analyses, control and irradiated IM-9 and IM-9 FLAG.Bcl-2 cells were fixed in $75 \%$ ethanol in PBS. Flow cytometric measurements were performed following addition of $\mathrm{PI}^{29}$

$2^{\prime}, 7^{\prime}$-Dichlorodihydrofluorescein diacetate $\left(\mathrm{CM}-\mathrm{H}_{2} \mathrm{DCFDA}\right)$ and dihydroethidium (DHE, Molecular Probes), two oxidation-sensitive fluorescent dyes commonly used for detecting cellular $\mathrm{H}_{2} \mathrm{O}_{2}$ or superoxide anion, respectively, were employed for measuring intracellular $\mathrm{ROS}^{10,11,24,46}$ DCFDA is the most widely used probe for measuring $\mathrm{H}_{2} \mathrm{O}_{2}$ levels. It is a cell-permeable, nonfluorescent molecule that provides an extremely sensitive method to follow redox changes over time. ${ }^{47}$ However, superoxide and NO generation are also capable of oxidizing DCFDA. Moreover, DCF, its oxidized fluorescent derivative, can leak out of cells over time, making difficult the detection of slow $\mathrm{H}_{2} \mathrm{O}_{2}$ production. Finally, cellular esterase activity is necessary for conversion of DCFDA to DCFH2, and in cells with low esterase activity DCFDA may underestimate the ROS levels. Nevertheless, use of both DCFDA and DHE provides a good estimate of ROS cellular changes. For determination of $\mathrm{H}_{2} \mathrm{O}_{2}$, cells were washed in serum-free medium twice, kept on ice, then stained in PBS $\mathrm{pH}$ 7.2) with $\mathrm{CM}-\mathrm{H}_{2}$ DCFDA $(1 \mu \mathrm{M})$ at $37^{\circ} \mathrm{C}$ for $5 \mathrm{~min}$, and examined by FACS with excitation at 488 and emission at $535 \mathrm{~nm}$. PI (to $10 \mu \mathrm{g} / \mathrm{ml}$ ) was added 1 min before flow cytometry. For determination of superoxide anions, cells were stained with DHE $(5 \mathrm{mM})$ in PBS $(\mathrm{pH} 7.2)$ at $37^{\circ} \mathrm{C}$ for $15 \mathrm{~min}$ and examined by FACS with excitation at 488 and emission at $620 \mathrm{~nm}$. To validate the data, $0.1 \mathrm{mM} \mathrm{H}_{2} \mathrm{O}_{2}$ was added $1 \mathrm{~h}$ before the staining. Bivariate flow cytometry was performed with a FACS scan, and the data were analyzed with a Cell Quest software (Becton Dickinson, San Jose, CA, USA) from the cell population from which apoptotic cells were gated out against forward and side scatter or Pl-positivity. Rhodamine 123 (R123) was used to determine $\Delta \psi_{\mathrm{m}}{ }^{27}$ in cells irradiated at different times, but all harvested at the same time, for staining. Cells were incubated with R123 $(0.5 \mathrm{mM})$ for $10 \mathrm{~min}$ at $37^{\circ} \mathrm{C}$ before flow cytometry. To validate the data, $m$-chlorophenylhydrazone (mCCP; $1 \mu \mathrm{M})$ was used after $10 \mathrm{~min}$ staining of cells by the above dyes. In parallel experiments, $100 \mathrm{nM}$ nonyl acridine orange (NAO) was used to determine mitochondrial mass. ${ }^{27}$

\section{Measurement of PT in isolated mitochondria}

Mitochondria were isolated from liver of Balb/c mice according to a standard protocol. ${ }^{35}$ Protein content of mitochondria was determined by the micro-biuret method, using BSA as standard. Mitochondrial swelling was monitored by the decrease of $90^{\circ}$ light scatter at $520 \mathrm{~nm}$ in the PT-1 medium at $25^{\circ} \mathrm{C}$, using a Jobin-Yvon FluoroMax-2 spectrofluorimeter.

\section{Measurement of GSH and GSSG by HPLC}

Cells $\left(2 \times 10^{6}\right)$ were washed twice with cold PBS, and $200 \mu$ l of $5 \%$ cold perchloric acid was added to precipitate proteins. Samples were then kept on ice for 15-20 min and centrifuged at $14000 \mathrm{rpm}$ for $15 \mathrm{~min}$. The pellets were further used for protein assays. The supernatants were transferred and mixed with $20 \mu \mathrm{l}$ of $240 \mathrm{mg} / \mathrm{ml}$ iodoacetic acid, followed by the addition of powder $\mathrm{KHCO}_{3}$ to neutralize $\mathrm{pH}$. The samples were then kept at $20^{\circ} \mathrm{C}$ in dark for 30 min before $220 \mu$ of $3 \%$ FDNB was added, and samples were analyzed at $365 \mathrm{~nm}$ by HPLC for reduced GSH or GSSG levels.

\section{Acknowledgments}

We thank Drs. SM Srinivasula, ES Alnemri (Thomas Jefferson University) for the caspase-9-DN, and G. Nunez (University of Michigan) for the pSFFV-FLAG.Bcl-2 constructs, and Ms. C Stanko (Cleveland Clinic Flow Cytometry Core) for help with flow cytometry. This work was supported by 
research grants from the National Institutes of Health to AA (CA81504 and CA82858) and GMC (HL29582).

\section{References}

1. Wang $X$ (2001) The expanding role of mitochondria in apoptosis. Genes Dev. 15: 2922-2933

2. Du C, Fang M, Li Y, Li L and Wang X (2000) Smac, a mitochondrial protein that promotes cytochrome c-dependent caspase activation by eliminating IAP inhibition. Cell 102: 33-42

3. Joza N, Susin SA, Daugas E, Stanford WL, Cho SK, Li CY, Sasaki T, Elia AJ, Cheng HY, Ravagnan L, Ferri KF, Zamzami N, Wakeham A, Hakem R, Yoshida H, Kong YY, Mak TW, Zuniga-Pflucker JC, Kroemer G and Penninger JM (2001) Essential role of the mitochondrial apoptosis-inducing factor in programmed cell death. Nature 410: 549-554

4. Li LY, Luo X and Wang X (2001) Endonuclease G is an apoptotic DNase when released from mitochondria. Nature 412: 95-99

5. Li W, Srinivasula SM, Chai J, Li P, Wu JW, Zhang Z, Alnemri ES and Shi Y (2002) Structural insights into the pro-apoptotic function of mitochondrial serine protease HtrA2/Omi. Nat. Struct. Biol. 22: 22

6. Li P, Nijhawan D, Budihardjo I, Srinivasula SM, Ahmad M, Alnemri ES and Wang X (1997) Cytochrome $c$ and dATP-dependent formation of Apaf-1/ caspase-9 complex initiates an apoptotic protease cascade. Cell 91: 479-489

7. Zou H, Henzel WJ, Liu X, Lutschg A and Wang X (1997) Apaf-1, a human protein homologous to $C$. elegans CED-4, participates in cytochrome $c$ dependent activation of caspase-3. Cell 90: 405-413

8. Thornberry NA and Lazebnik Y (1998) Caspases: enemies within. Science 281: $1312-1316$

9. Voehringer DW, McConkey DJ, McDonnell TJ, Brisbay S and Meyn RE (1998) Bcl-2 expression causes redistribution of glutathione to the nucleus. Proc. Natl. Acad. Sci. USA 95: 2956-2960

10. Hockenbery DM, Oltvai ZN, Yin XM, Milliman CL and Korsmeyer SJ (1993) Bcl2 functions in an antioxidant pathway to prevent apoptosis. Cell 75: 241-251

11. Kane DJ, Sarafian TA, Anton R, Hahn H, Gralla EB, Valentine JS, Ord T and Bredesen DE (1993) Bcl-2 inhibition of neural death: decreased generation of reactive oxygen species. Science 262: 1274-1277

12. Voehringer DW (1999) BCL-2 and glutathione: alterations in cellular redox state that regulate apoptosis sensitivity. Free Radic. Biol. Med. 27: 945-950

13. Steinman HM (1995) The Bcl-2 oncoprotein functions as a pro-oxidant. J. Biol. Chem. 270: 3487-3490

14. Kluck R, Bossy-Wetzel E, Green D and Newmeyer D (1997) The release of cytochrome $\mathrm{C}$ from mitochondria: A primary site for $\mathrm{Bcl}-2$ regulation of apoptosis. Science 275: 1132-1136

15. Yang J, Liu X, Bhalla K, Kim C, Ibrado A-M, Cai J, Peng T-I, Jones DP and Wang X (1997) Prevention of apoptosis by Bcl-2: release of cytochrome $c$ from mitochondria blocked. Science 275: 1129-1132

16. Vander Heiden MG, Chandel NS, Williamson EK, Schumacker PT and Thompson CB (1997) Bcl-xL regulates the membrane potential and volume homeostasis of mitochondria. Cell 91: 627-637

17. Vander Heiden MG and Thompson CB (1999) Bcl-2 proteins: regulators of apoptosis or of mitochondrial homeostasis? Nat. Cell Biol. 1: E209-216

18. Marzo I, Brenner C, Zamzami N, Jurgensmeier JM, Susin SA, Vieira HL, Prevost MC, Xie Z, Matsuyama S, Reed JC and Kroemer G (1998) Bax and adenine nucleotide translocator cooperate in the mitochondrial control of apoptosis. Science 281: 2027-2031

19. Petit PX, Lecoeur H, Zorn E, Dauguet C, Mignotte B and Gougeon ML (1995) Alterations in mitochondrial structure and function are early events of dexamethasone-induced thymocyte apoptosis. J. Cell Biol. 130: 157-167

20. Slater AF, Nobel CS and Orrenius S (1995) The role of intracellular oxidants in apoptosis. Biochim. Biophys. Acta. 1271: 59-62

21. Jacobson MD and Raff MC (1995) Programmed cell death and Bcl-2 protection in very low oxygen. Nature 374: 814-816

22. Goossens V, Grooten J, De Vos K and Fiers W (1995) Direct evidence for tumor necrosis factor-induced mitochondrial reactive oxygen intermediates and their involvement in cytotoxicity. Proc. Natl. Acad. Sci. USA 92: 8115-8119
23. Li PF, Dietz R and von Harsdorf R (1999) p53 regulates mitochondrial membrane potential through reactive oxygen species and induces cytochrome c-independent apoptosis blocked by Bcl-2. EMBO. J. 18: 6027-6036

24. Polyak K, Xia Y, Zweier JL, Kinzler KW and Vogelstein B (1997) A model for p53-induced apoptosis. Nature 389: 300-305

25. Wong GH and Goeddel DV (1988) Induction of manganous superoxide dismutase by tumor necrosis factor: possible protective mechanism. Science 242: 941-944

26. Melov S, Coskun P, Patel M, Tuinstra R, Cottrell B, Jun AS, Zastawny TH, Dizdaroglu M, Goodman SI, Huang TT, Miziorko H, Epstein CJ and Wallace DC (1999) Mitochondrial disease in superoxide dismutase 2 mutant mice. Proc. Natl. Acad. Sci. USA 96: 846-851

27. Chen Q, Gong B and Almasan A (2000) Distinct stages of cytochrome c release from mitochondria: evidence for a feedback amplification loop linking caspase activation to mitochondrial dysfunction in genotoxic stress induced apoptosis. Cell Death Differ. 7: 227-233

28. Chen $Q$, Gong B, Mahmoud-Ahmed A, Zhou A, Hsi ED, Hussein M and Almasan A (2001) Apo2L/TRAIL and Bcl-2-related proteins regulate type I interferon- induced apoptosis in multiple myeloma. Blood 98: 2183-2192

29. Almasan A, Yin Y, Kelly RE, Lee EY, Bradley A, Li W-W, Bertino JR and Wahl GM (1995) Deficiency of retinoblastoma protein leads to inappropriate S-phase entry, activation of E2F-responsive genes, and apoptosis. Proc. Natl. Acad. Sci. USA 92: $5436-5440$

30. Haliwell B and Gutteridge JMC (1989) In Free Radicals in Biology and Medicine, 2 ed., Oxford: Clarendon Press, pp 1-81

31. Gong B, Chen Q, Endlich B, Mazumder S and Almasan A (1999) lonizing radiation-induced, Bax-mediated cell death is dependent on activation of serine and cysteine proteases. Cell Growth Differ. 10: 491-502

32. Armstrong JS, Steinauer KK, Hornung B, Irish JM, Lecane P, Birrell GW, Peehl DM and Knox SJ (2002) Role of glutathione depletion and reactive oxygen species generation in apoptotic signaling in a human B lymphoma cell line. Cell Death Differ. 9: 252-263

33. Higuchi M, Honda T, Proske RJ and Yeh ET (1998) Regulation of reactive oxygen species-induced apoptosis and necrosis by caspase 3-like proteases. Oncogene 17: 2753-2760

34. Ott M, Robertson JD, Gogvadze V, Zhivotovsky B and Orrenius S (2002) Cytochrome $c$ release from mitochondria proceeds by a two-step process. Proc. Natl. Acad. Sci. USA 99: 1259-1263

35. Xia T, Jiang C, Li L, Wu C, Chen Q and Liu SS (2002) A study on permeability transition pore opening and cytochrome $c$ release from mitochondria, induced by caspase-3 in vitro. FEBS Lett. 510: 62-66

36. Boveris A and Chance B. (1973) The mitochondrial generation of hydrogen peroxide. General properties and effect of hyperbaric oxygen. Biochem J. 134: 707-716

37. Cai J and Jones DP. (1998) Superoxide in apoptosis. Mitochondrial generation triggered by cytochrome $c$ loss. J. Biol. Chem. 273: 11401-11404

38. Tan S, Sagara Y, Liu Y, Maher P and Schubert D (1998) The regulation of reactive oxygen species production during programmed cell death. J. Cell. Biol. 141: 1423-1432

39. Green D and Kroemer G (1998) The central executioners of apoptosis: caspases or mitochondria? Trends Cell Biol. 8: 267-271

40. Susin SA, Zamzami N, Castedo M, Daugas E, Wang HG, Geley S, Fassy F and Reed JC, Kroemer G (1997) The central executioner of apoptosis: multiple connections between protease activation and mitochondria in Fas/APO-1/ CD95- and ceramide-induced apoptosis. J. Exp. Med. 186: 25-37

41. Goldstein JC, Waterhouse NJ, Juin P, Evan Gl and Green DR (2000) The coordinate release of cytochrome $c$ during apoptosis is rapid, complete and kinetically invariant. Nat. Cell Biol. 2: 156-162

42. Gross A, McDonnell JM and Korsmeyer SJ (1999) BCL-2 family members and the mitochondria in apoptosis. Genes Dev. 13: 1899-1911

43. Robertson JD, Enoksson M, Suomela M, Zhivotovsky B and Orrenius S. (2002) Caspase-2 acts upstream of mitochondria to promote cytochrome $c$ release during etoposide-induced apoptosis. J. Biol. Chem. 13: 13

44. Guo Y, Srinivasula SM, Druilhe A, Fernandes-Alnemri T and Alnemri ES (2002) Caspase-2 induces apoptosis by releasing proapoptotic proteins from mitochondria. J. Biol. Chem. 277: 13430-13437

45. Lassus $P$, Opitz-Araya $X$ Lazebnik $Y$. Requirement for caspase-2 in stressinduced apoptosis before mitochondrial permeabilization. (2002) Science. 297: 1352-1354 
46. Macho A, Hirsch T, Marzo I, Marchetti P, Dallaporta B, Susin SA, Zamzami N and Kroemer $G$ (1997) Glutathione depletion is an early and calcium elevation is a late event of thymocyte apoptosis. J. Immunol. 158: $4612-4619$
47. Curtin JF, Donovan M and Cotter TG (2002) Regulation and measurement of oxidative stress in apoptosis. J. Immunol. Methods 265: 49-72

48. Simonian PL, Grillot DA and Nunez G (1997) Bcl-2 and Bcl-XL can differentially block chemotherapy-induced cell death. Blood 90: 1208-1216 